\title{
Comparative Study of Motivation Aspect as Part of Productive Behavior on the Senior High School and Boarding School Students in Cirebon
}

\author{
Hanny Hafiar \\ Communication Faculty \\ Padjadjaran University \\ Bandung Indonesia \\ Hery Wibowo \\ Social and Political Science Faculty \\ Padjadjaran University \\ Bandung Indonesia
}

\author{
Diana Harding \\ Psychology Faculty \\ Padjadjaran University \\ Bandung Indonesia \\ Titin Nurhayati Ma'Mun \\ Cultural Science Faculty \\ Padjadjaran University \\ Bandung Indonesia
}

\begin{abstract}
Every action is driven by a specific motive. The motive is also a catalyst for the growth of productive behavior. Each student who attended various educational institutions eventually hopes to have a job as a handle for the future, whether as an employee or entrepreneur. But without a good work ethic, it is difficult for individuals to have a job and earn an income corresponding to the needs. It is therefore important for each student to have high motivation as part of the work ethic to be competitive in obtaining employment. Therefore this study seeks to examine the motivations of students who attended high school and boarding schools equal. The method used is descriptive study, with data collection techniques using questionnaires, which are distributed to high school and boarding school students in Cirebon taken purposively. As for the results show that there are some aspects of the indicators of motivation in where high school students are higher than boarding school students namely: can motivate themselves, persevering on a task to complete, have a willingness to work hard, like a challenge. Nevertheless, there is still a motivation that is not optimal among high school students. This is caused not only by the education system received but also due to the influence of environmental factors, both family, and friends where they hang out. Therefore it needs to be done in the system status, presumably learning so that students can have a high motivation in achieving a certain achievement.
\end{abstract}

\section{Keywords: motivation, productive behavior, students, high school, boarding school}

\section{INTRODUCTION}

Teenagers are the younger generation who became the nation's assets. In the hands of this young generation of the nation's future was at stake. Therefore, it has become a shared obligation to prepare teenagers for the younger generation in order to be ready to receive the baton relay development. It refers to: "Teenagers have a lot of options and interest in his life, one of them about the future. Plan and determine the future requires students to know their interests, abilities, good self-acceptance that will become the benchmark for success " (Aisyah, 2015).

According to Freud (in Suryabrata, 1998) that children up to the age of approximately five years through the phases of differentiated dynamically, then up to the age of $12 / 13$ years experienced latent phase, a phase in which the dynamics become more stable. With the advent of adolescence (puberty) the dynamics erupt again, and the more tranquil when people got older. For Sigmund Freud, a period until the age of 20 years decisive for the formation of one's personality. It means someone who can pass through adolescence with happy will become an adult with personality and vice versa. (Azizah, 2013).

On average, they who are in this age range are studying in senior high school. There are many activities that are provided by the school as a place for teenagers to increase the potential and competence. Most teens take advantage of this opportunity well, but others do not have an awareness to enhance the potential and competence. In fact, though not felt, in a few years to come they should start searching for jobs in an attempt to earn a living and continue to the next life stage.

Unconsciousness from teenagers in preparing for the future in order to be ready to compete in the world of work can not be separated from the motivation factor. Motivation is also dealing with issues of interest. According to Rokhimah (2015), interest is one factor that will determine the success of a person both in terms of studies, work or other activities (Nurrohmatulloh, 2016). While the motivation which is derived from the word 
motive means encouragement, for reason or someone does something (Rahmawati, 2013). As for the other explanation regarding motivation, expressed as follows: "Motivation is a factor that encourages someone to do a particular activity. Motivation is one of the important and influential factors to productivity "(Hamali, 2013).

According to the results of some research, especially concerning human resources mentioned that motivation has a significant influence towards increasing work productivity. Employee achievements are the result of work that can be accomplished by a person or group of people in an organization in accordance with the authority and responsibilities of each, in order to achieve the objectives of the organization (Rahmawati, 2013).

Motives that encourage teens to have a future orientation tend still not strong, it is in line with the characteristics of teenagers who are still in the stage of emotionally unstable. This is in line with the statement that: "Teenagers today have faced problems. Their physical and mental maturity being offset by accelerating the maturation of emotions and their freedom of increasing cause problems experienced by adolescents become more complex "(Prihartini, Nuryoto, \& Aviatin, 2002).

Some educational institutions have its own way in preparing their students. The specificity of the educational style depends on the vision and mission of the institution that became the orientation of the institution in the achievement of the expected output. But in essence, every educational institution is aware that one of their responsibilities is to prepare their students in order to compete and compensate for the rapid development of the times in which more and more weight in their demands. One of the demands of economic competition today is the quality of human resources that have the work ethic and productivity.

Mubyarto (1992) states: The word ethos comes from the Greek that has a meaning of attitude, personality, feature, character, as well as the belief in something. This attitude is not only owned by individuals, but also by groups of society (Kurniasih, 2013). Professional work ethic is a key route leading to the road of success. Without the work ethic along with full professionalism, we might easily slip into the ranks of the losers. Without awareness to enhance the professionalism of the work ethic in all sports, we might soon become beings who stutter with the changing dynamics. Poor of achievement, and the absence of a long journey towards productive human, noble and dignified. One of the attitudes that support the high work ethic is the discipline of work (Titisari, Warso, and Haryono, 2016). A good work ethic can be shown through the attitude of empathy and tolerance in the work environment. If someone wants to love his job with sincerity, then he would be a rich personal nature and easy to serve others with happiness. Love at work is a way of life that will enrich a person's life in all aspects of life (Probowati, 2008).
Work ethic is a soft skill that should be owned by every individual. No matter how great the achievements of students in the academic field, is not a guarantee of ease in the future because academic performance is only one of the prerequisites that are usually used as a benchmark in the job application. However, after the individuals directly involved in the world of work, skills they have will be the determinant of the brilliance of one's career.

In Indonesia, the institution of high education senior high schools in Indonesia, consisting of several types, including general, vocational, or boarding school. The specificity of the education system is certainly related to the graduates produced. If vocational schools do indeed have established areas of work that will be entered by the prospective graduates, the different thing with public senior high schools and boarding schools. Most of the graduates it is prepared to continue to pursue higher education studies, though not all of its graduates willing and able to pursue higher education. In connection with the college, said that:

"Act No. 12 of 2012 states that in order to enhance the nation's competitiveness in the face of globalization in all areas, required higher education are able to develop science and technology and produce intellectuals, scientists, and/or professional cultured and creative, tolerant, democratic, strong character, and dare to defend the truth for the sake of the nation. This is exactly what reveals the demand for soft skills training (characters) student "(Setuju, 2015).

In line with this statement, it is clear that the work ethic and productivity can determine the competitiveness of nations. That is, the work ethic is a competency that requires the support of motivation. Therefore, this study intends to examine the motivation of advanced middle school students and boarding school as part of a work ethic that should be developed in the human resources to be able to cope with global competition. The study used the quantitative descriptive method. The data obtained by collecting data based on the answers to the questionnaire distributed to a number of senior high school students and boarding school that equivalent to senior high school level.

\section{MOTIVATION COMPARISON AS PART OF PRODUCTIVITY}

In principle, "Ways of addressing a member of grammar rules and social norms, both written and unwritten actually formed from cohesivity and confidence levels of each of its members associated with the overall goal of educational institutions. Not surprisingly, a similar educational institution, which draws inspiration from the same source, can be a very noticeable difference in daily practices because the school culture is not formed. School culture is formed 
through a relational pattern among members when responding to certain issues, or how schools take a stance and decision against something real problem.

One of the uniqueness and excellence of a school is to have a solid school culture and still exist. A school must have a mission to create a school culture that is challenging and fun, fair, creative, integrative, and dedicated towards achieving the vision, producing quality graduates high in intellectual development and has the character of piety, honest, creative, able to be exemplary, hardworking, tolerant and proficient in the lead, and answer the challenge of the need for the development of human resources that can contribute to the development of science and technology and based on the IMTAQ ," (Supraptiningrum \& Agustini, 2015)

Most graduates of senior high schools and boarding schools aspire to work right after school. But not all real graduates are ready to work. This refers to the user's response stating that graduates now tend to not have a soul of leadership, including to lead themselves to be more productive. Leadership or leadership comes from the leaders, the leader is an individual who leads, manage, motivate or inspire others. They are men or women who influence others in an organization or a particular community. Deborah J Barrett (2008) in his book Leadership Communication says that leadership and communication are the two things that related. Without effective communication, the leader itself cannot achieve its purpose well. Without effective communication, a leader cannot be effective (Artawan, Shintadewi, \& Budiana, 2016).

Based on the results of questionnaires collected, the data obtained as follows:

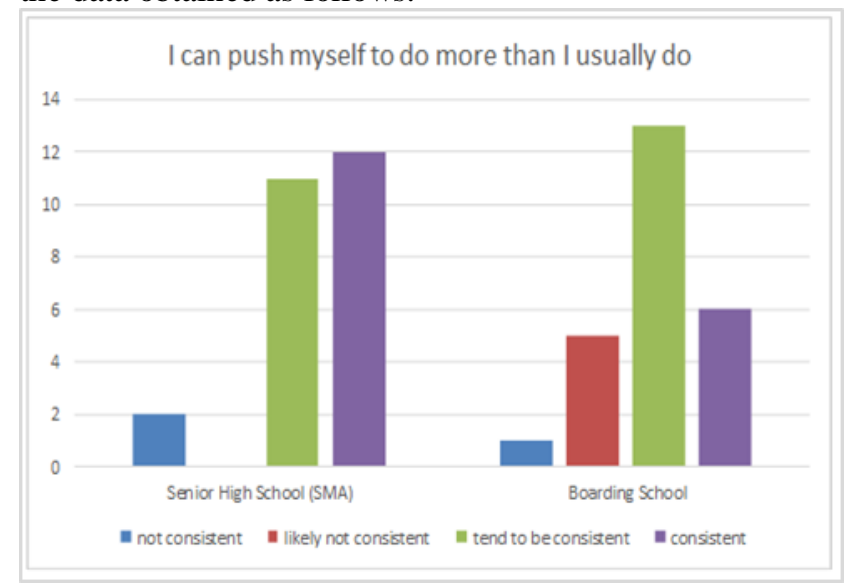

Figure 1 The desire to push themselves to be able to do more

Based on the table, it appears that the desire to push themselves to do more than usual to senior high school students is higher than boarding school students. It provides an understanding that the majority of senior high school students have a certain mental attitude and have the potential productivity to push themselves to do with a better way. Work productivity includes the mental attitude that always has a view of life on the implementation of the production in a company where the production is expected to be better than yesterday. Everyone will always strive to make improvements in its work so that the outcome for the better (Setiati, 2010).

The desire to push themselves to do better is an important capital for a person to become a productive individual. This is consistent with the suggestion that: "A productive workforce is labor deft and produce goods and services according to defined quality with less time or when the workforce is capable of producing a product or a greater output of other labor in a long time" (Pajar, 2008). Next up is the perseverance in the face of challenges.

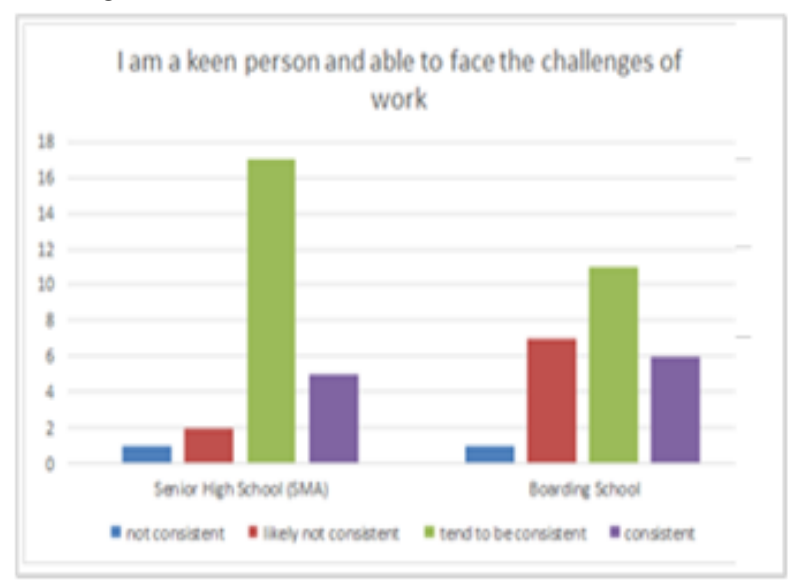

Figure 2 Perseverance in the face of challenges

Perseverance is part of the human character. This is because the basic human character consists of trustworthy, caring, respect and caring, honesty, responsibility, and citizenship, sincerity, brave, diligent, disciplined, fair, and have integrity. (Burn, 2016). According to Sinamo (2005), every human being has a spirit/spirit of success, that is pure motivation to achieve and enjoy success. This is the spirit that transformed into typical behavior such as hard work, discipline, conscientious, diligent, integrity, rational, responsible and so on through the conviction, commitment and appreciation of the specific work paradigm.

Perseverance is also the important part which must be owned by a person who is interested in becoming entrepreneurs. According to Siagian \& Asfahani (1996) the entrepreneurial values include a strong willingness to work and independent, able to make the right decision and dare to take risks, creative and innovative, diligent conscientious and productive, as well as working with the spirit of togetherness and a healthy business ethics (Hafiar \& Sani, 2015). Thus, every entrepreneur is required to have perseverance.

Still with regard to perseverance, Elliot \& Dweck (in Pintrich \& Schunk, 1996) states that a positive character is a character who refers to himself, focusing on the development of expertise and skills related to the duties and performance of the past that can help develop behavioral achievement more appropriate, such as 
developing options for a better challenge, positive assumptions about the efforts and diligent and persistent in the face of failure (Mayasari, 2011). Next, the data will be presented about a willingness to work hard.

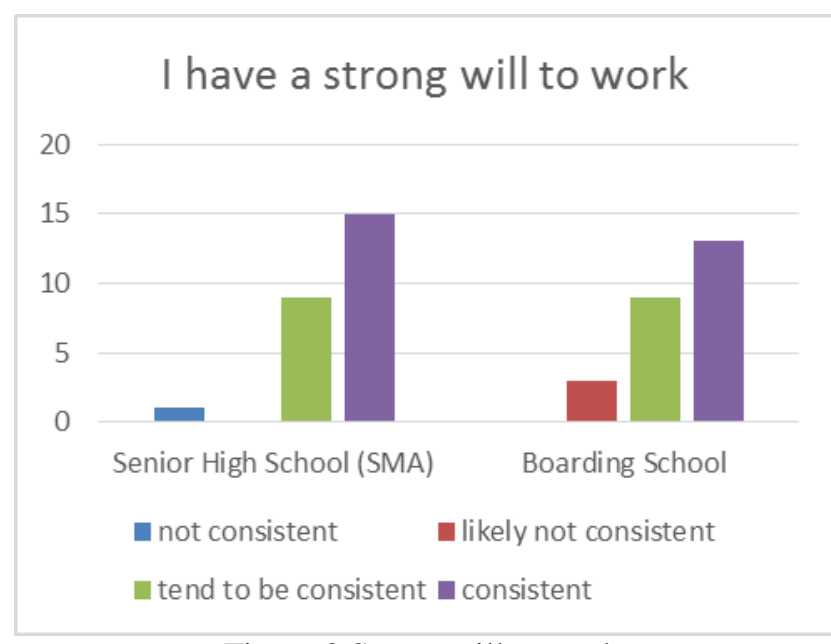

Figure 3 Strong will to work

The strong will to work is owned mostly senior high school students is higher than boarding school students. According to psychologists, there are some character values include: love of God and His creation (nature with its contents), responsibility, honesty, respect and courtesy, compassion, caring, cooperation, confidence, creativity, hard work and perseverance, justice and leadership, kind and humble, tolerant, peaceloving, and love unity (Bakar, 2016). The Strong will to work also includes a willingness to comply with the norms and regulations, including norms in the form of demands set out in the working environment. This is consistent with the statement of Jerry Wyckoff and Barbara C. Unel in Sudrajat, (2008: 2) states that labor discipline is awareness, willingness and the willingness of the labor of others to be obedient and subject to all the rules and norms (Titisari et al. , 2016).

Success in the field of entrepreneurship can not be separated from the hard work and high motivation. This refers to the statement: "the necessary motivation in running an online business so that the business be more productive to increase their income and promote the business being operated" (Yasundari, 2016). The next item is the comparison of the preferences of the challenge.

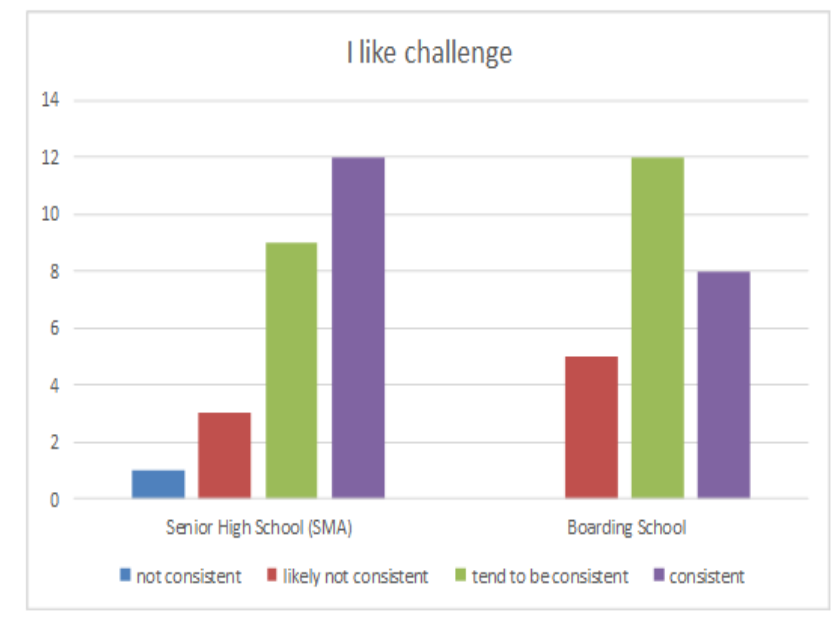

Figure 4 Like challenge

Like challenges, attitude is an important gesture that should be owned by every individual, because every job has its own challenges that are dynamic. Dynamic work will refrain from boring routine. It is filled to the statement that:

"The work ethic is the attitude, outlook, habits, traits or the nature of how to work belonging to a person, a group or a nation. A high work ethic certainly routines will not make bored, even able to improve its performance. The basis of the high work ethic in them the desire to uphold the quality of the work, then the individual has a high work ethic will participate and provide inputs ideas in the workplace "(Dodi, Yusuf, and Amri, 2013).

In principle, the challenges will make the working environment becomes more dynamic. Working climate is also a part that can boost productivity can develop optimally. According Sedarmayanti (2001: 12) the various factors that affect work productivity among other mental attitudes such as work motivation, work discipline and work ethic, education, skills, management of industrial relations Pancasila, the level of income and health, social security, social environment and work climate, production facilities, technology and achievement opportunity (Purnama, 2003).

Therefore, a need to increase knowledge can make the individual insights about the world of entrepreneurship can be expanded through a variety of reading materials, we need information about the literacy skills of entrepreneurs in order to foster entrepreneurship motivation (Khadija, Fortune, Sukaesih, \& Anwar, 2016). The next discussion will be undertaken with regard to the desire to make improvements continuously. 


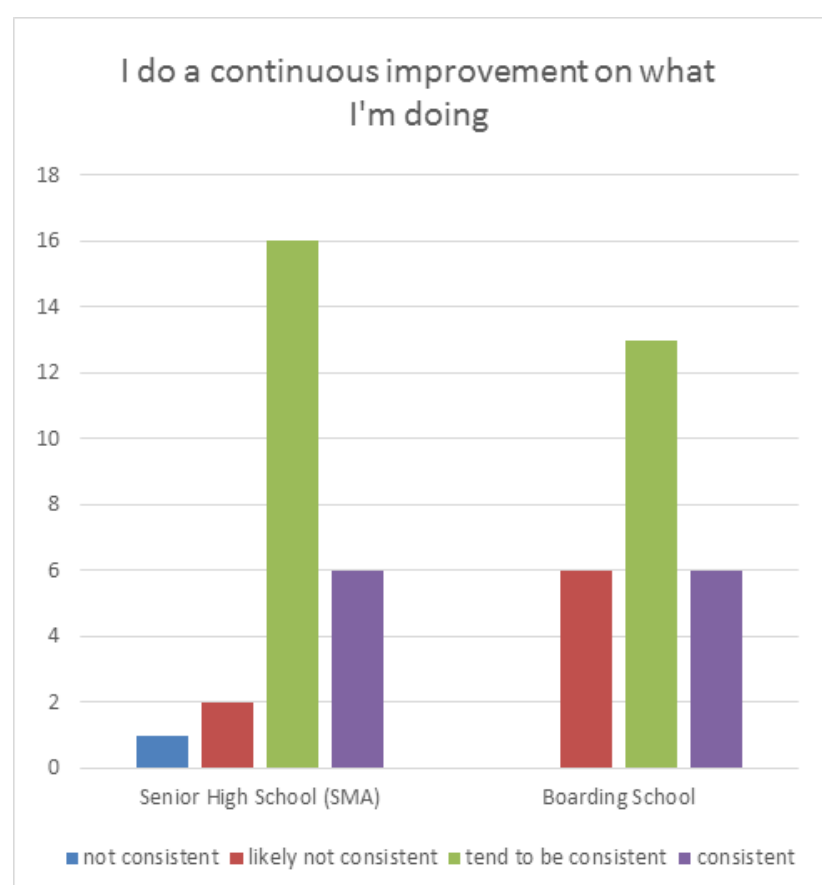

Figure 5 Perform continuous improvement

In essence, Islam is a religion that upholds work ethics as defined by the word of Allah in the Qur'an Surah at-Taubah verse 105: "Do as you will. Allah, His Rasul, and the believers will now keep a watch over your conduct; then you shall be brought to His court Who knows the hidden and the open, and He will inform you of all that you have done." It can be interpreted that every worker is mainly Muslim, should be able to grow in Islamic work ethic, because the work that occupied valuable worship. The results of his work can also be used for the purposes of worship, including supporting the family. Therefore, the selection of employment foster Islamic work ethic a must for all jobs (Mahmudah, 2015).

Therefore, the need of value investment in educational institutions that raise awareness to always make improvements over time. This kind of character education requires a system of cultivation of character values that include components of knowledge, awareness or willpower, and measures to implement the great value both to themselves and others. Character education in schools needs to involve all stakeholders components, including an educational component itself such as curriculum, learning and assessment, treatment or management of the school, and work ethic throughout the school environment (Zainuddin, 2015).

\section{CONCLUSIONS AND SUGGESTIONS}

Based on the findings from the field data note that aspects of motivation which is part of the student's work ethic, which includes: The desire to push themselves to do more, perseverance in the face of challenges, strong will to work, Love a challenge, and doing continuous improvement of the senior high school and boarding school student who are in Cirebon that have more or less the same level and equal.

Even if there are differences, the rate differences This is due to the education system that is applied in both educational institutions of origin of respondents equally apply educational system based on the development of the characters, including characters that support the strengthening of motivation and work ethic formation in an effort to prepare students to become the successor to the baton of the nation's economic development.

As for the recommendations that can be recommended include the need for the introduction of the working world orientation exists for the students to get to know the profession and job prospects of interest, especially for students who plan to work after graduating from senior high school. In addition, it also required guidance and counselling for students who don't already have a future orientation, so that when they leave school no longer confused in determining future goals.

\section{REFFERENCES}

Aisyah, S. (2015). Hubungan self esteem dengan orientasi masa depan pada siswa sma kelas xi di sma negeri 3 malang. Skripsi. UIN Maulana Malik Ibrahim Malang.

Artawan, G. A. W. M., Shintadewi, E. A., \& Budiana, H. R. (2016). Makna Kegiatan Unilever Future Leaders League Bagi Para Peserta. Profesi Humas, 1(1), 1-11.

Azizah. (2013). Kebahagiaan dan Permasalahan di Usia Remaja Tantangan perubahan yang dibawa oleh era globalisasi. Jurnal Konseling Religi, 4(2), 295-316.

Bakar, M. Y. A. (2016). Pembentukan karakter lulusan melaluinpembelajaran bahasa arab di pondok modern lirboyo kediri. JOIES, 1/1, 27-68.

Dodi, R., Yunus, M., \& Amri. (2013). Pengaruh iklim organisasi, etos kerja dan disiplin terhadap kinerja karyawan serta dampaknya pada kinerja PT. Arun NGL Lhokseumawe Aceh. Jurnal Manajemen Pascasarjana Univ Syiah Kuala, 2(1), 98-107.

Hafiar, H., \& Sani, A. (2015). Pembentukan Sikap Wirausaha Remaja Melalui Komunikasi Keluarga Dan Pelatihan Keterampilan. Jurnal Actadiurna, 11/1, 49-66.

Hamali, A. Y. (2013). Pengaruh Motivasi Terhadap Produktivitas Kerja: Studi Kasus Pada Pt X Bandung. Jurnal The Winners, 14/2, 77-86.

Khadijah, U. L., Rejeki, D. S., Sukaesih, S., \& Anwar, R. K. (2016). Literasi Informasi Dalam menumbuhkan motivasi Berwirausaha Bagi Para Ibu Rumah Tangga Di Kelurahan Nagasari Kabupaten Karawang Barat. Jurnal Kajian Informasi \& Perpustakaan, 4(2), 149-160.

Kurniasih, R. (2013). Etos kerja komunitas pemulung dalam mempertahankan hidup di bantaran sungai gajah wong kota yogyakarta. Skripsi. UIN Sunan Kalijaga. Yogyakarta.

Mahmudah, H. (2015). Analisis etos kerja pemulung 
dalam meningkatkan kualitas hidup di kecamatan tikung lamongan. JEBIS, 1(2), 143-160.

Mayasari, D. (2011). Pengaruh orientasi tujuan dan motivasi belajar terhadap prestasi belajar siswa sma peserta bimbingan belajar LBB Primagama. Skripsi. UIN Syarif Hidayatullah Jakarta, 1-93.

Nurrohmatulloh, M. A. (2016). Hubungan orientasi masa depan dan dukungan orang tua dengan minat Melanjutkan Studi Ke Perguruan Tinggi. E-Journal Psikologi.fisip-Unmul, 4(4), 446-456.

Pajar. (2008). Analisis faktor-faktor yang mempengaruhi produktivitas kerja karyawan bagian keperawatan pada rumah sakit PKU Muhammadiyah Surakarta. Skripsi. Universitas Muhammadiyah Surakarta.

Prihartini, T., Nuryoto, S., \& Aviatin, T. (2002). Hubungan Antara Komunikasi Efektif Tentang Seksualitas Dalam Keluarga Dengan Sikap Remaja Awal Terhadap Pergaulan Bebas Antar Lawan Jenis. Jurnal Psikologi, (2), 124-137.

Probowati, A. (2008). Membangun sikap dan etos kerja. Jurnal Segmen Manajemen, 1. Retrieved from http://ejournal.umpwr.ac.id/index.php/segmen /article/view/256

Purnama, R. (2003). Pengaruh Motivasi Kerja Terhadap Produktivitas Kerja Karyawan Pada Bagian Produksi CV . Epsilon Bandung. Jurnal Strategic. Jurnal Pendidikan Manajemen Bisnis, 7/14, 58-72.

Rahmawati, D. (2013). Pengaruh motivasi terhadap produktivitas kerja karyawan PT. Fajar Berlian Tulungagung. Jurnal Universitas Tulungagung Bonorowo, 1(1), 1-16.

Setiati, J. (2010). Analisis Faktor-Faktor Produktivitas Kerja Pada pegawai Perpustakaan ITS. Universitas Airlangga, (71211623008), 2-3.

Setuju. (2015). Penguatan Karakter Mahasiswa dalam Menghadapi MEA. Seminar Dan Call Paper, Dies Natalies Universitas Sarjanawiyata Taman Siswa $\mathrm{Ke}$ 60,1-12.

Supraptiningrum, \& Agustini. (2015). membangun karakter siswa melalui budaya sekolah di sekolah dasar. Jurnal Pendidikan Karakter, V/2, 219-228.

Titisari, Warso, M., \& Haryono, A. T. (2016). Analisis pengaruh karakteristik organisasi, etos kerja dan disiplin kerja terhadap performa perusahaan dengan efektifitas kinerja karyawan sebagai variabel intervening. Journal Of Management, $2 / 2$.

Yasundari. (2016). Hubungan penggunaan instagram dengan motivasi wirausaha pebisnis daring ( online ) dalam meningkatkan produktivitas. Jurnal Kajian Komunikasi, 4/2, 208-218.

Zainuddin, M. (2015). Implementasi kurikulum 2013 dalam membentuk karakter anak bangsa. Universum, 9/1, 131-139. 